\title{
New Zealand's Counter-terrorism Strategy: A Critical Assessment
}

Authors: John Battersby, Rhys Ball and Nick Nelson

To cite this article: Battersby, J., Ball, R., \& Nelson, N. (2020). New Zealand's Counterterrorism Strategy: A Critical Assessment. National Security Journal.

doi:10.36878/nsj20200201.05

To link to this article: https://doi.org/10.36878/nsj20200201.05

View CrossRef data: https://search.crossref.org/?q=10.36878\%2Fnsj20200201.05 


\title{
NEW ZEALAND'S COUNTER-TERRORISM STRATEGY: A CRITICAL ASSESSMENT
}

\author{
John Battersby, Rhys Ball and Nick Nelson ${ }^{1}$
}

\begin{abstract}
In mid-February 2020 New Zealand released its long overdue 'Countering terrorism and violent extremism national strategy' This article draws on the experience of three academic commentators who cast a critical eye over the document and whose respective thoughts are brought together here. The approach taken is to discuss the purpose and fundamentals of what strategy is to provide a framework with which to review New Zealand's first publicly released counter-terrorism strategy. Unfortunately, this important and long overdue strategy, in the view of the authors, comes up well short of what it should be. The authors offer a challenge to New Zealand's policy makers concerned with national security to seek more depth in the consideration of their approach, to present a strategy with less graphic design, more substantial discussion of the fundamental questions relating to the management of modern terrorism and violent extremism, and an appreciation of the nuanced New Zealand experience with political violence from late twentieth century to the present day.
\end{abstract}

Keywords: New Zealand, Counter-terrorism, Violent Extremism, Countering Terrorism and Violent Extremism National Strategy, Political Violence, Stolberg, Department of Prime Minister and Cabinet, Terrorism

\section{Introduction}

Unlike its Five Eyes partners, for the first two decades of the $21^{\text {st }}$ century New Zealand perceived itself as little affected by terrorism of any kind and until very recently possessed no specific publicly available national strategy for countering terrorism. Two years after the 1985 Rainbow Warrior incident, the International Terrorism (Emergency Powers) Act was enacted, allowing certain powers in the case of an international terrorist event occurring in New Zealand. ${ }^{1}$ These powers were only vaguely useful at the time and in the main have been supplanted by subsequent legislation. Unsurprisingly the Act has never been used. Following the 9/11 attacks, and to remain in line with international obligations, New Zealand introduced the Suppression of Terrorism Act in 2002. ${ }^{2}$

1 Dr John Battersby is a Teaching Fellow, Dr Rhys Ball is a lecturer and Mr Nick Nelson a Senior Lecturer with the Centre for Defence and Security Studies, Massey University. Contact (Corresponding author) j.m.battersby@massey.ac.nz 
Controversy has haunted this Act, its definition, design, tautology and application have all been problematic and it was not until the worst mass killing in New Zealand's modern history occurred in 2019 - the 15 March terrorist attack in Christchurch - that an actual charge was laid under it. Amendments to the Act have been made from time to time, but these were reactions to international expectations, and no underlying strategy existed to govern or guide how New Zealand should approach the impact of international terrorism generally, let alone how it might deal with the manifestation of terrorism on home soil. The release of the 'Countering terrorism and violent extremism national strategy', in February 2020, some five months after Cabinet approval, was a major step forward in New Zealand's realisation that it needed to be visibly better prepared to coordinate a national approach to counter terrorism from high-level policy, to legislation, through to practice on the ground.

The aim of this paper is to evaluate New Zealand's first publicly released counterterrorism strategy. To provide a framework for this evaluation, a brief exploration of what strategy is will be made along with a review of what might be considered core elements of any security strategy. The paper will then undertake a cursory review of the counter-terrorism strategy documents of New Zealand's Five Eyes partners against this framework prior to evaluating each section of the New Zealand strategy in detail. In considering each section of this strategy document, the authors seek to overview purpose and effectiveness by drawing out the complexity that lies beneath the activity outlined. In doing this, the authors provide insights into how New Zealand's strategy might be enhanced to clearly identify, and better address, the threat posed by terrorism. This is a critical approach, but it is also designed to be constructive. By highlighting the importance and value in presenting a comprehensive foundational document focused on all of the key aspects of contemporary counter-terrorism, the authors hope to persuade those responsible for subsequent iterations of the strategy to adopt a more detailed, less public relations-oriented, approach.

\section{What is Strategy?}

The term 'strategy' is used, and abused, in various contexts. There are grand strategies, corporate strategies, financial strategies, sports strategies and so on. For these reasons, strategy has become something of an elastic concept, layered by misunderstanding and ambiguity, often overlooked in contemporary policy debates and frequently avoided by policymakers. ${ }^{3}$ At its core though, strategy is about the direction and use made of means by chosen ways in order to achieve desired ends. ${ }^{4}$ From a national security perspective, strategy is a serious business which "lies at the interface between operational capabilities and political objectives and is the glue which binds each to the other and gives both sense". ${ }^{5}$ In wartime, security strategy can mean the difference between success and defeat, or life and death. In peacetime it ensures that threats to security can be either managed, defeated or, ideally, prevented before they become security issues. For this 
reason, understanding strategy as well as how to develop it, is essential for the survival of a nation. ${ }^{6}$ With this in mind, along with recent security issues related to terrorism in New Zealand - most notably the events of the 15 March 2019 attacks in Christchurch, the authors were pleased to learn that a long overdue New Zealand 'Countering terrorism and violent extremism national strategy'2 had been developed and released into the public domain by the Department of Prime Minister and Cabinet (DPMC). ${ }^{7}$

The development of strategy and the placing of it into the public domain serves several purposes according to Stolberg. ${ }^{8}$ Firstly, it works as a broad construct for various government agencies to ensure that they understand the intent of the political officials of the day. Secondly, it informs the legislative body within a country of the resource requirements for the strategy and, in doing so, facilitates the fiscal approval processes. Thirdly, strategy serves as a communications tool for both domestic and foreign audiences. In addition to the various purposes of strategy, DuMont ${ }^{9}$ identifies certain basic elements that a security strategy should contain to be complete and coherent, as well as a range of additional elements that are not strictly necessary for a strategy to be viable but which can enhance the ability to implement it by a nation state. For efficiency, this article will focus only on the basic, or core, elements which include:

- an endorsement by the head of government,

- an accurate reflection of national values,

- a clear articulation of national interests,

- a declaration of strategic vision,

- an identification and assessment of future challenges,

- a risk assessment,

- an overview of required resources,

- an effective timeframe,

- measures of effectiveness, and

- basic implementation guidance.

While all of these are considered core elements, it is acknowledged that the extent to which these can be covered in any specific strategy document may vary considerably.

\section{Counter-Terrorism Strategies of our Five Eyes Partners}

Armed with a framework for understanding the purpose for, and core elements of, a security strategy, the authors cast an eye over the counter-terrorism strategies of other nations, specifically our Five Eyes partners. While all present unique considerations to terrorism specific to their own particular nation, and share certain commonalities, they

$2 \quad$ The authors refer to the strategy as the 'Countering terrorism and violent extremism national strategy'. The pdf document of the strategy uses the full title 'Countering terrorism and violent extremism national strategy overview' on p.1. The authors concluded that 'overview' referred to p.1. only. On the DPMC website the strategy document is referred to only as 'New Zealand's Counter-Terrorism Strategy'. See https://dpmc.govt.nz/publications/new-zealands-counter-terrorism-strategy. 
are comprehensive and coherent documents that meet the criteria identified above. The 2015 Australian Counter-Terrorism Strategy, proceeded two national counter-terrorism White Papers released in 2004 and 2010. ${ }^{10}$ The current 2015 strategy Strengthening Our Resilience, a 31-page document, outlines the framework for Australian counter-terrorism arrangements, but importantly "situates the current terrorism threat for Australia within both the domestic and global contexts" and "articulates how we are countering it." ${ }^{11}$ The document, offers the flexibility to adapt to these two changing environments - which has been a hallmark of its approach to terrorism throughout its history, and particularly since 11 September 2001. It is designed to complement the country's National CounterTerrorism Plan that outlines governance and jurisdictional arrangements, as well as operational responsibilities for "preventing, preparing, responding to and recovering from domestic terrorist attacks." ${ }^{12}$ The Australian document, like the British strategy, emphasises that prevention is the "first line of defence against terrorism.." ${ }^{13}$ Australia's strategy is endorsed with the signature of the Prime Minister of the day, Tony Abbott.

The United Kingdom's Counter Terrorism Strategy 2018 (CONTEST) $^{14}$ is a comprehensive and detailed-100 page document clearly building on lessons from previous counter-terrorism approaches. ${ }^{15}$ CONTEST is the product of a review of the UK's previous strategy which was first developed as a classified document in 2002 and publicly released four years later. ${ }^{16}$ CONTEST sets out to "respond systematically and proportionately" to terrorism and it outlines in some detail a four-stage approach, its global and local context, implementation, resourcing, roles and responsibilities. It is endorsed with the signature of then British Prime Minister, Teresa May and Home Secretary, Sajid Javid.

The first Canadian counter-terrorism strategy was published in $2012 .{ }^{17}$ Canada's current 50-page counter-terrorism strategy is a full and detailed document covering various terrorist threats based on international and domestic, internal and external experience. Goals are set and measurable outcomes stated for each aspect of implementation. The plan for countering terrorism is outlined. The strategy explicitly deals with roles and responsibilities, legal frameworks and implementation. It is endorsed by Vic Toews, the Minister of Public Safety. ${ }^{18}$

The United States 2018 National Strategy for Counterterrorism is a shorter, but nonetheless decisive 34-page document that clearly articulates the 'how' and offers a "more agile and expansive approach that addresses the full spectrum of terrorist threats... including enemies overseas and the people they seek to influence and mobilize violence in the United States." ${ }^{19}$ The current US strategy, like the British iteration provides a list of end-state measurables or performance indicators, admittedly broad, but which define the success of the strategy. ${ }^{20}$ The document is endorsed by the current US President Donald Trump. 
The authors note that these strategies are not immune to criticism, and the extent to which they meet the above requirements of sound strategy do vary one from another. Suffice to say, that reading these strategies from cover to cover takes time, and while the description and detail varies and approaches differ, they are full and informative documents that leave the reader clear on the direction each nation is taking and why it has taken that direction. The reader is well informed on what the end state is intended to be, and aware of both how, and with what, each nation proposes to obtain it. They provide a useful comparison for New Zealand as to how other nations strategies meet the framework established above.

\section{New Zealand's Countering terrorism and violent extremism national strategy}

New Zealand's 'Countering terrorism and violent extremism national strategy', unlike its much more robust Five Eyes partners, comprises a meagre six pages. Each page is dedicated to a separate topic - (1) an Overview, (2) Aims, (3) Counter-terrorism handbook, (4) Counter-terrorism work programme (5) Counter-terrorism coordinated public information, and (6) Public information action plan. Other than on page 1, none of the headings include the term 'violent extremism', and this rather important aspect of the policy seems to ebb and flow erratically throughout. The pages are presented in landscape orientation, with much of the space taken up with graphic illustrations. Rumelt tells us that a sign of "mediocrity and bad strategy is superficial abstraction-a flurry of fluff-designed to mask the absence of thought" by presenting a "generous sprinkling of buzzwords that masquerade as expertise." ${ }^{\text {"1 }}$ New Zealand's strategy document risks this criticism. The sparse explanatory text is spread out in formatted blocks, stretched to occupy what appears to be, due to the paucity of information presented, an over generous allocation of space. By comparison to our Five Eyes partners' strategy documents, New Zealand's strategy looks like it is still in its conceptual state - a 'work in progress' rather than the finished product.

It is entirely appropriate that strategy in the national security realm is drafted and coordinated by national security staff - in New Zealand's case the Counter Terrorism Coordination Committee (CTCC) housed at DPMC but reporting to the Security and Intelligence Board (SIB). As DuMont ${ }^{22}$ notes, to ensure that the strategy drafted is an accurate reflection of the government's intent, and to have the gravitas to ensure its effective implementation, it must have the authoritative approval of at least one senior government official, and ideally the head of the government. Not only does this confirm approval at the highest political level, it also signals a willingness to ensure the strategy is adequately resourced to ensure its effective implementation. While its official release at the Otago Foreign Policy School in February 2020 was accompanied by the Prime Minister, her signature is starkly absent from the document itself. As referred to above, leaders (or responsible Minister in the case of Canada) of New Zealand's Five Eyes 
partner nations have formally and physically endorsed their respective national strategy documents without exception. Is the New Zealand Government taking counterterrorism less seriously than its partners?

The logos of 14 government agencies are imprinted on page 2 of New Zealand's strategy document, reflecting the 'All of Government' approach which has prevailed in New Zealand for some years now. This approach suggests coordination, integration and efficiency in resourcing between state agencies, but it has pitfalls too. In particular, Mesier argues that there is a risk 'All of Government' approaches may actually foster bad strategy because officials do not "have to think about what should be done to solve a national security problem, the answer is already there, no matter what the problem." ${ }^{23}$ Such broad-based, comprehensive approaches, he adds, merely offer "a solution waiting to be applied to every problem." ${ }^{24}$ The 'All of Government' approach is the pre-determined solution, leaving the more deep-seated actual extant problems unaddressed. In contrast to those of our Five Eyes partners, New Zealand's strategy can be read in a few minutes. This brevity leaves the reader with more questions than answers in what appears to be a plethora of undeveloped policy directions. It leaves the strategy open to wide interpretation; it is a document that can ultimately mean anything anyone wants it to.

For a strategy to be understood, receive widespread approval, and be resourced, it must take into account and underpin a nation's values. On page 1 of New Zealand's strategy there is the isolated statement of "Standing together as a nation and championing our values against terrorism and violent extremism" 25 without any discussion of what these values may be. A separate cabinet paper supporting this strategy noted that the way in which New Zealand responded to the Christchurch attack championed the values of "tolerance, democracy and unity" ${ }^{26}$, and that the aim is to "reinforce the values that were at the heart of our initial response." But it is unclear whether, and how, these values have contributed to the development of the current strategy, let alone how might this strategy keep "New Zealanders safe by leveraging our high levels of trust." ${ }^{27}$ Similarly, there is no clear articulation of national interests which bridge the link between values and goals.

By way of declaration of a strategic vision, New Zealand's strategy has an aim (ends) section on page 2 and what are assumed to be a number of 'abstract' goals - reduction, readiness, response, recovery referred to in a separate cabinet document as pillars. ${ }^{28}$ The stated aim of the strategy "Bringing our nation together to protect all New Zealanders from terrorism and violent extremism of all kinds" ${ }^{29}$ is a broad, all-encompassing statement but one that raises a number of issues, key among them being what is meant by the terms 'terrorism' and 'violent extremism'. No international consensus exists on these terms, and New Zealand's definition of terrorism in the Terrorism Suppression Act (2002) is convoluted, likely conceived without any real appreciation of how terrorism has evolved either nationally or internationally. ${ }^{30}$ The Ministry of Justice has recently reviewed the Suppression of Terrorism Act, including its definition of an act 
of terrorism, and to its credit they consulted diligently and fully on many aspects of this review. But the government has yet to act, and even if it does, it is unlikely to do so before the 'Royal Commission of Inquiry into the Attack on Christchurch Mosques report' is released. A clear understanding of what the strategy document means by these key terms is essential - and while it does provide definitions of them, they are in the small print (somewhat out of place as a footnote on page 4), reflecting an assumption that discussion about them is not needed. Vandenberg and Hoverd provide a useful discussion on the use of these terms in detail (in this volume of National Security Journal) stressing that considerable thought and discussion are, indeed, necessary.

Strategy in the security realm should be, by its very nature, forward-looking and bring together the strands of a nation's strategic environment by looking at how hidden currents today signal possible changes in future direction. This provides important strategic context that allows for a full range of future possibilities to be identified and prepared for. While this is far from an exact science, undertaking and articulating the logic upon which the strategy has been developed is essential for its successful implementation. Unfortunately, New Zealand's strategy is almost entirely lacking in this and little understanding can be gleaned as to why it has been developed in the way it has or what foreseeable threats it is designed to address. It is of course acknowledged by the authors, that these issues are touched on, albeit inadequately, in a separate September 2019 cabinet paper. ${ }^{31}$ Flowing on from this, the strategy fails to undertake any clear form of risk assessment to ensure that any risks identified can, if possible, be mitigated.

The strategy does not provide any indication of required resources (means) - an important requirement which allows for the advocacy of the resources that are essential to ensure the strategy's effective implementation - although there are a series of non-specific financial implication statements of the strategy in a separate document. ${ }^{32}$ Nor does the strategy provide an effective time-frame other than for a public information plan. Measures of effectiveness are similarly lacking. These are all key elements vital to ensure the effective implementation of the strategy as well as the accountability of those responsible for its implementation. Their absence is of considerable concern given the potential impact on the longer-term security of the nation. This is particularly so with the onset of a global recession that will see government resources stretched. If no thought to resourcing was given previously, it may be extremely challenging to pitch for them in the post-COVID 19 economic environment. If this happens, terrorism and counter-terrorism in New Zealand will revert back to its former position of being a largely neglected concern. That is until the next attack.

Finally, in terms of the core elements of the document, the strategy provides little in the way of implementation guidance (ways) other than the broad sweeping statement that "We will achieve our aim by: working in partnership, ensuring as a nation that we connect with each other, supporting the efforts of the international community, and fo- 
cussing on prevention." ${ }^{33}$ These are underpinned by five areas: legislation, governance, public information, a responsive national security system, and capabilities ${ }^{34}$ without any further substantive discussion. While it is acknowledged that there are significant security considerations that limit what may be included in terms of implementation information in the public domain, and the near-term is likely to see amendments to a number of relevant statutes, the detail here is still inadequate.

\section{'Our response: Counter-terrorism handbook' and 'Counter-terrorism work programme'}

The section entitled 'Our response: Counter-terrorism handbook', left the authors wondering whether this section was the 'handbook' per se, or signaled the existence of, or determination to produce, one. Subsequently in the 'Counter-terrorism work programme' section (page 4) of the document, a brief reference is made to the counterterrorism handbook 'refresh', suggesting that a 'handbook' is extant, and that it is to be reviewed. As it stands, the 'Our response' section of the strategy appears to be merely a 'check-sheet' for senior members of the Officials' Committee for External and Domestic Security Coordination (ODESC) in the case of a terrorist event occurring. Obviously there is a need to maintain a high level of confidentiality about the details of any such 'counter-terrorist handbook', and full disclosure of strategic, operational and tactical elements are not expected here, but nor should there be ambiguity about whether 'a counter-terrorism handbook' exists or not. Indeed, if it is not something the public are ever going to see, why mention it at all?

The 'Counter-terrorism work programme' (page 4) is stated to be 'evolving' post 15 March. It comprises a series of topics which relate to counter-terrorism, but it does not constitute a coherent programme with development stages and time-frames, and appears more the result of ideas jotted onto a page that are worth exploring, reflecting the relatively recent practice of egalitarian 'mind-mapping' workshops, as opposed to applying a genuine strategic thought process. These ideas contain little internal logic or explanation as to how they relate to one another, or together how they necessarily relate to countering terrorism. It was surprising to note the absence of a 'risk assessment' aspect of the work programme, a fundamental requirement as previously discussed. It is possible the 'risk profile' refers to this, but the absence of explanatory text leaves it ambiguous. The reference to 'arms reform' and 'the Christchurch call' were independently developed and reactive aspects of existing government policy. Other components of the 'work programme' appear to be peripherally related to counterterrorism but require explanation for their presence in this document - for example 'Drones guidance,' 'Transport security work programme,' and 'Border systems' convey insufficient information on how they are conceived as tenets of a counter-terrorism approach. 


\section{Counter-terrorism coordinated public information}

The fifth section of New Zealand's counter-terrorism strategy claims that "the Christchurch terrorist attack highlighted what we've known for some time - New Zealand is not immune to terrorism." ${ }^{35}$ But who is 'we?' It is true that people within New Zealand's security sector were indeed aware that terrorism was a credible threat, but recent research which looked at the period before 15 March 2019, showed considerable wider societal and bureaucratic ambivalence about the potential risk of terrorism here. ${ }^{36}$ Those who did suspect the risk, faced resistance from the much greater part of government, the state sector and broader society generally who actually gave the possibility of terrorism little thought.

The public information section of the strategy also asserts that a comprehensive work programme to support "an inclusive, engaged, aware and well-informed society" is required and that: "We will consult with, and get input from, a wide range of stakeholders, including government agencies, Iwi, NGOs, councils and communities." ${ }^{37}$ It casts terrorism as a widespread social problem, presuming that within "iwi, NGOs, councils and communities" there is untapped expertise to not only understand it, but to counter it also - when this may not necessarily be the case. The risk of terrorism has traditionally been ignored by most sections of New Zealand society. Those 'stakeholders' listed within the strategy are no exception.

Not all terrorism or violent extremism is the same. States that have deeply divided political fault lines, or disenfranchised minorities (or occasionally majorities) have tended to develop secessionist, or revolutionary organisations which have adopted terrorism as a tactic and rooted themselves into the political fabric of those states. The Greek-Cypriot EOKA, Colombian FARC, Algerian FLN, Spanish ETA and the IRA to name a few, ran violent terrorist campaigns for years which only political solutions could ultimately mitigate. While this is often considered 'old terrorism' - in reality militant secessionist organisations such as the Continuity IRA, New IRA, ETA, and the Kurdish PKK have all been active in terrorism in the 2010s. New Zealand has never had a secessionist terrorist organisation, and while this historical pattern is suggestive of a future without one - it is not a certainty that some form of ethno-nationalist terrorist movement will not germinate here. If faced with such a threat, "an inclusive, engaged" society will be a long way off.

New Zealand has experienced two short periods of connected sequential political violence. These comprised mainly individuals acting alone or in small groups using bombings, bomb threats and deliberate hoaxes, roughly aligned with strong protest movements and oriented towards changing government policy regarding New Zealand involvement in the Vietnam War (1965-1975) and the Springbok tour (1981). These were deeply polarising social and political issues which prompted mass protest, heavy state enforcement action, and ultimately produced individuals who decided that 
'peaceful protest' was not enough. It is wishful thinking to assume that further divisive political issues will not create similar catalyst platforms in the future. No matter how genuine the government is in seeking an engaged and inclusive society, the reality is that a range of issues will cause differences, perhaps even polarise society, including the apparently ineffectual measures taken to combat climate change, the continuing use of 1080, the legalisation of abortion, the gun buy-back, the predicted severe economic disparity post-COVID 19, and the assumption that everyone will, or should, accept multi-culturalism as a positive goal in an age of identity politics.

The experience of Western Europe, especially post-war Germany, and post-colonial France, Belgium and others have highlighted that carelessness in managing multiethnic and multi-cultural diversity can lead to parallel and disjointed communities, where newcomers co-exist with established populations, prompting insecurities (and perceived threats to identity) among all groups. The French colonial legacy with Algeria in the second half of the twentieth century, was partly behind the susceptibility of its minority communities to ISIS inspired terrorism in the mid-2010s. ${ }^{38}$ More recent concerns have emerged in Sweden, which in 2015 took more refugees per capita than any other country in Europe and was observed to lead "to racial tensions and integration issues in Swedish towns and cities and, worryingly, an increase in homegrown far-right, racist and xenophobic groups." 39 The rise of Right Wing Extremism in Europe and the US has been noticeable over the past two decades.

New Zealand deliberately avoided multi-culturalism after World War II, embracing it genuinely only in the early twenty-first century. ${ }^{40}$ But New Zealand's diversity came quickly. In 2016 the city of Auckland was considered more diverse than Los Angeles, New York and London, with 39\% of its inhabitants born overseas. While other cities were proactive in managing lesser levels of diversity, New Zealand was described at the time by migration expert Paul Spoonley as having a "very relaxed and relatively non-interventionist approach" which until then at least "appeared to be working". Read slightly differently, this suggests New Zealand was actually doing nothing about confronting the potential challenge of diversity and instead relied on the well-known "she'll be right" principle and hoping for the best. In 2020 an Auckland Council report revealed that half of Aucklanders viewed "ethnic and cultural diversity" negatively, suggesting that problems that have already surfaced in Europe may indeed be coming to roost here. ${ }^{42}$ The concentration of many émigré refugee communities into single areas within particular suburbs over the last 30 years may have been done with the best intentions, but the medium-to-long term consequences were never given sufficient consideration from socio-economic, much less security, perspectives. The COVID 19 crisis prompting huge numbers of ex-pats to return home is unlikely to aid better relationships between peoples of different nationalities.

Complicating the social inclusion goal is the incongruity between New Zealand's increasingly bi-cultural approach in public policy (which could have been remarkably 
fitting a hundred years ago) and the reality of New Zealand's increasingly multi-cultural ethnic make-up. ${ }^{43}$ New Zealand's sudden embracing of diversity was fundamentally economically driven, designed to exploit the wealth and skills of foreigners, rather than any genuine commitment to actually embracing them. Abuse directed at an Indian New Zealand Police Officer at the Ihumatao land occupation and New Zealand First Government Minister Shane Jones' defending his repeated offensive comments about Indian people on the grounds that he was Maori, suggests a dilemma that New Zealand has not yet resolved. ${ }^{44}$

If one theme does stand out in New Zealand's history of terrorism and political violence, it is that individually driven, and often completely isolated, lone actors have emerged out of the blue and taken unexpectedly violent action. These occasions were outlined in a previous issue of the National Security Journal..$^{45}$ While the 15 March 2019, was unprecedented in terms of its scale, in almost every other sense it was typical of New Zealand's most identifiable expressions of political violence; lone actors, loosely associated with broader ideological sympathisers, but actually unconnected behaviourally from them, who easily disguised their intentions and planned their threats unseen. They neither followed nor inspired any prolonged trend. They did not present a broad-based social problem, nor were the vast bulk of other socially isolated people (even if they did share similar outlooks) ever actually dangerous. The wide range of consultation suggested in the strategy document reflects the collective All of Government' approach to contemporary national security issues, but nevertheless seems to misinterpret the nature of New Zealand terrorism. It presumes that New Zealand terrorism presents a significant social problem when all the evidence to date points to a vastly less, very difficult to define, intermittent, serious but limited, and nuanced type of unusual violence.

While overseas and New Zealand experience does show community based and NGO interventions can effectively and beneficially rehabilitate those who want a way out of certain extremist poles, the NGOs with actual competence in this area are few in number. New Zealand agencies have engaged with certain Muslim communities in dealing with those few individuals who were caught up with ISIS's online extremism in the 2010s. This was successful but not without its problems identified by both security practitioners and Muslim community members. ${ }^{46}$ Dealing with Right Wing Extremists (RWE) is a somewhat different matter, however. They appear to exist in New Zealand in no great number. ${ }^{47}$ We would observe also that they are currently without a socially accepted moderating broader group through which 'community engagement' could be easily facilitated to reach those dwelling in the extremes. This differs from Europe where numbers of reformed ex-RWE members are actively engaged in programmes counselling people away from neo-Nazi groups. To neglect 'consultation' with some credible connector to the RWE 'community' would be to leave a marginalised group vulnerable to causational drivers that lull young individuals to extremism. 
As Vandenberg and Hoverd point out, extremism is not necessarily terrorism, and confronting one will not necessarily reduce the other. Norway boasted one of the most effective counter RWE programmes, before Anders Brevik emerged undetected to carry out deadly attacks in Oslo and Utoya Island in July $2011 .^{48}$ Brevik's action demonstrates the complexity of this form of modern terrorism, and that despite highly successful deradicalisation programmes, the occasional and genuinely dangerous individual can still circumvent them all. This underpins the importance of serious thought and discussion on concepts like 'extremism' and 'violent extremism'. The New Zealand strategy needs to identify which parts of the community can provide meaningful input into prevention, early intervention of at-risk individuals and critically how it manages the likely success of these initiatives, if faced with a single and devastating failure - like Norway's. This reinforces earlier discussion above about the need for measurable success indicators.

\section{The proposed public information action plan}

The final section of the Strategy document 'Public information action plan' uses the phrase 'public information' ten times, and the emphasis is clearly less on countering terrorism and violent extremism, and more on providing the public with information in the event of having failed to do so. Indeed, the cabinet paper submitted along with the draft strategy in September 2019 identified a clear intention of proposing a "new communications strategy for Counter-Terrorism." ${ }^{49}$ New Zealand's recent experience of COVID 19 saw an initially well-organised, well-informed, soundly communicated strategy to react to the disease, to contain it and attempt to eliminate it. New Zealanders had no basis to complain that they did not receive timely, easy to understand information and advice about what to do at the onset of the level 1-4 approach. Even so, many simply ignored it, many initially refused to take the reality of community transmission seriously or to take precautions that would have reduced the risks of it spreading, in many cases standing in queues of potentially infected people for protracted periods of time to purchase quantities of food they did not need. Supermarkets ran out of toilet paper, sugar, flour, soap and - and barely a year since the 15 March mass killing in Christchurch, there was even panic buying of guns and other weapons. ${ }^{50}$ In one day alone, supermarket chain Countdown reported that it sold enough food to feed 10 million people, twice the New Zealand population..$^{51}$ This should provide the authors of the strategy document cause to reflect on the genuine utility of providing the public with information, and question why such emphasis needs to be placed on it. The authors contend far more strategic emphasis should be placed on countering the messaging from terrorist perpetrators and denying them the audience they seek. This falls into the 'prevent' category more than the 'response' one and reflects what the authors believe is a need for a far more proactive strategy.

The 'Public information action plan' relies heavily on illustrations and arrows to outline a timeline for work under various headings to progress including: 
- Social inclusion,

- The Christchurch Call and related work,

- Crowded Places strategy public information,

- Public messaging on how to stay safe during a terrorism attack,

- Tip-off messaging,

- Annual threat environment report,

- The gun buy-back campaign,

- A Terrorism and violent extremism language resource,

- Media engagement, and a

- Counter-terrorism public information review.

Enough has been said here about the difficulties of social inclusion. The Christchurch Call to date has revealed how genuinely impossible it is to control the content of social media platforms. One security commentator has opined recently that the Christchurch Call may not last beyond Prime Minister Jacinda Ardern's tenure as Prime Minister, being a policy very much linked to her personally. ${ }^{52}$ New Zealand has done some, but not much, Crime Prevention Through Environmental Design (CPTED) and the concept has only a few genuine qualified practitioners in New Zealand. It has also done little in terms of securing public spaces from lone actor shooters, bombers, vehicular attackers or other more improvised attack modes. The vast number of public places, streets and private-public venues in New Zealand, where potentially such attacks could occur, will be a major barrier to positive progress here. The Australian 2017-released Strategy for Protecting Crowded Places from Terrorism - ironically authored by the Australia-New Zealand Counter-Terrorism Committee (ANZCTC) - explicitly and quite literally links to terrorism. Probably prompted by the ANZCTC a New Zealand Crowded Places Strategy has been the offing for some time, but it has still not been publicly released so how well it links to New Zealand's 'Counter terrorism and violent extremism national strategy' remains unclear. ${ }^{53}$

Public messaging on how to stay safe in a terrorist attack is widely accessible on the internet, available for anyone to read - including prospective and potential terrorists planning their attacks. Whether this messaging is effective or not is largely unresearched. Tip-off messaging is available already, has identified potential risks in New Zealand and should be continued. The annual threat environment report is a continuance or simple extension of existing annual government agency reporting and is not new.

The Gun buy-back campaign has been incorporated in the strategy document. The immediate suspension of over-the-counter purchasing of Military Style Semi-Automatics (MSSAs) was inevitable and necessary to prevent a repeat of $15 \mathrm{March}$, but the further step of a buy-back required some fuller consideration. There has been significant international research on the effectiveness of arms reform involving gun buy-backs as a crime mitigation approach. However different researchers using various methodolo- 
gies have come to opposite conclusions, often using the same evidence. Much research attention has been given to the National Firearms Agreement which overhauled arms control in Australia following the mass killing in Tasmania in 1996. Many claims have been made, but no conclusive outcomes have resulted despite over 20 years of research. ${ }^{54}$

A key limitation of these studies is the absence of comparisons between nations undertaking arms control measures and nations not doing so at the same time. New Zealand did not undertake any firearms reform similar to Australia's and maintained after 1996 effectively what Australia changed - and yet, firstly gun crime in New Zealand remained low as Australia's did, secondly New Zealand homicides continually declined into the 2000's to historically low levels, as did Australia's, and finally, New Zealand had no mass shootings after 1996, until 2019.

Researchers generally approach the issue of gun control as a crime (specifically guncrime) reduction measure. None have considered it as a counter-terrorism measure, most likely because a gun buy-back has not been applied anywhere specifically as a terrorism mitigation response. Norway did not ban semi-automatic weapons in 2011, although decided to do so in 2018, but has not yet implemented it. ${ }^{55}$ Canada has just announced a ban on MSSA's in the wake of its most recent and worst mass killing, but again not as a counter terrorist initiative. ${ }^{56} \mathrm{New}$ Zealand's application of a gun buyback as a plank in its counter-terrorism strategy is stretching into unexplored territory, hoovering up a populist government reaction - which like Canada's - appears optically decisive in a time of crisis but to date it lacks the evidential foundation to be placed confidently into a national counter terrorism strategy.

Under the heading - "Terrorism and violent extremism language resource" the strategy document shows DPMC in charge of creating:

a one-page resource for government agencies, media and public commentators to support the use of consistent and appropriate language around terrorism and violent extremism - in particular that does not incite or stigmatise[.]

The subsequent heading looks at developing strong relationships with the media and 'content specialists' to better understand the roles of the government, the media and the public. The pre-determination of "one page" being a "resource" sufficient for any purpose continues the questionable belief in brevity already discussed above. The comment on "consistent and appropriate language" and strong relationships with the media and "content specialists" (whatever a "content specialist" is) suggests an attempt to control not only what independent experts may say, or be reported as saying, but attempting to govern the language they use in saying it. There is a great deal of debate globally about the nature of terrorism, extremism and violent extremism, radicalisation and securitisation and there is much disagreement among a great many perspectives 
grappling with this wickedly complicated set of phenomena. Is it the role of DPMC to decide on what "consistent and appropriate" is, in relation to media, academic, other independent expert or "content specialist" commentary on these subjects? Or should various alternative perspectives be encouraged in an effort to develop useful and, potentially, counter intuitive insights into how New Zealand might best address the threats posed by contemporary terrorism?

\section{Conclusion}

It will come as no surprise to the reader that the authors conclude New Zealand's 'Countering terrorism and violent extremism national strategy' is too short, under-developed and lacks evidence of a genuine knowledge base of contemporary terrorism, or violent extremism, trends. There is also insufficient appreciation of the relative success or failure of various international counter terrorism and counter violent-extremism responses. The strategy itself appears disconnected from New Zealand's own nuanced, but nevertheless actual, 50-year experience of political violence and lacks many of the components one would expect to see enunciated in such an important document as this.

Noting these deficiencies has compelled the authors to speculate as to the purpose for which the strategy was developed and disseminated in the first place. As previously discussed, Stolberg ${ }^{57}$ outlines several purposes for the development of strategy and the placing of it in the public domain. The first two of these - that it serves as a broad construct for understanding political intent, and that it informs the legislative body within a country of the resource requirements - seem almost impossible to achieve with the strategy in its current form. This led the authors to think that the third suggested purpose - that it serves as a communications tool for both domestic and foreign audiences - is the key reason it was developed. If this is the case, the authors are left wondering who the intended audience is for New Zealand's strategy, for no one with even a limited understanding of, or passing interest in the topic, would be able to glean much of value from it.

The authors consider that New Zealand's 'Countering terrorism and violent extremism national strategy' would be considerably strengthened by a clear articulation of national interests and a concise statement of both the actual and future challenges New Zealand expects to encounter. This statement would recognise past manifestations of terrorism domestically, as well as current and projected future trends internationally. Because, as Nobel Laureate Niels Bohr notes, ${ }^{58}$ "prediction is very difficult, especially if it's about the future", the strategy should contain a comprehensive risk assessment that enables a prioritised approach to be adopted towards achievement of the strategy's goals. In turn, this will allow clearly defined areas of responsibility to be designated to agencies, with real people committed to its implementation, as well as the identification, advocacy and acquisition of the resources required to achieve the strategy. Finally, 
the strategy must contain examples of success and failure, as well as explicit measures of effectiveness, including timeframes, that quantify the results to be obtained and ensure accountability - both of those responsible for the implementation of the strategy and for the government of the day.

Dwight Eisenhower notes in his wartime memoir Crusade in Europe "The basic principles of strategy are so simple that a child may understand them. But to determine their proper application to a given situation requires the hardest kind of work from the finest available staff." ${ }^{9} 9$ Much hard work remains to be done on New Zealand 'Countering terrorism and violent extremism national strategy' to ensure it is a complete and coherent document that offers a way to develop an "optimal, long-term counter-terrorism policy approach" ${ }^{60}$ and equally present a coherent and contemporary understanding of how to effectively protect New Zealand from the threat posed by terrorists and violent extremists.

1 See New Zealand International Terrorism (Emergency Powers) Act 1987. Available at: www.legislation.govt.nz/act/public/0179/DLM124823.html

2 See New Zealand Terrorism Suppression Act 2002. Available at: www.legislation.govt.nz/act/public/2002/0034/DLM151491.html

3 John Gearson \& Hugo Rosemont, "CONTEST as Strategy: Reassessing Britain's Counterterrorism Approach," Studies in Conflict \& Terrorism, 38:12 (2015), pp.1041-1042.

4 Colin Gray, Perspectives on Strategy (Oxford: Oxford University Press, 2013).

5 Hew Strachan, The Direction of War: Contemporary Strategy in Historical Perspective (Cambridge: Cambridge University Press, 2014), p. 12.

6 Aaron Edwards, Strategy in War and Peace (xEdinburgh: Edinburgh University Press, 2017).

7 Department of Prime Minister and Cabinet, Countering Terrorism and Violent Extremism: National Strategy Overview. Retrieved from https://dpmc.govt.nz/sites/default/files/2020-02/2019-20\%20CT\%20 Strategy-all-final.pdf

8 Alan Stolberg, How Nation States Craft National Security Strategy Documents (Pennsylvania: Strategic Studies Institute, 2012).

9 Malia DuMont, Elements of National Security Strategy. Retrieved from https://www.atlanticcouncil. org/content-series/strategy-consortium/elements-of-national-security-strategy/

10 The 2004 Counter-Terrorism White Paper: Protecting Australia Against Terrorism, and the 2010 Counter-Terrorism White Paper Securing Australia/Protecting Our Community.

11 Commonwealth of Australia (2015). Australia's Counter-Terrorism Strategy: Strengthening Our Resilience, p. v.

12 Ibid, p. v.

13 Ibid, p. vi.

14 HM Government, “CONTEST: The United Kingdom's Strategy for Countering Terrorism, (2018). Available at https://assets.publishing.service.gov.uk/government/uploads/system/uploads/attachment_ data/file/716907/140618_CCS207_CCS0218929798-1_CONTEST_3.0_WEB.pdf

15 The 2018 publication is the fourth iteration of the strategy. Ibid, p.13. 
16 John Gearson \& Hugo Rosemont, "CONTEST as Strategy: Reassessing Britain's Counterterrorism Approach,” Studies in Conflict \& Terrorism, 38:12 (2015), pp.1039-1040.

17 Terrance Carter \& Nancy E. Claridge, Canada's Counter-Terrorism Strategy Targets Environmentalism," Anti-Terrorism \& Charity Law Alert No.31, 30 May 2012. Available at www.carters.ca/pub/alert/ ATCLA/ATCLA31.pdf

18 The Government of Canada (n.d) 'Building Resilience Against Terrorism: Canada's Counter-Terrorism Strategy. Available at https://www.publicsafety.gc.ca/cnt/rsrcs/pblctns/rslnc-gnst-trrrsm/rslnc-gnsttrrrsm-eng.pdf

19 United States Government (2018). National Strategy for Counterterrorism of the United States of America, October 2018. Washington DC., p.2

20 United States Government (2018). National Strategy for Counterterrorism of the United States of America, October 2018. Washington DC, p.1. United Kingdom Government (2018). CONTEST: The United Kingdom's Strategy for Countering Terrorism, Presented to Parliament by the Secretary of State for the Home Department by Command of Her Majesty, June 2018. London, HMSO, p.87.

21 Richard Rumelt (2011). 'The Perils of Bad Strategy' in McKinsey Quarterly 1, No.3, pp.5-6.

22 Malia DuMont, Elements of National Security Strategy. Retrieved from https://www.atlanticcouncil. org/content-series/strategy-consortium/elements-of-national-security-strategy/

23 Jeffrey W. Meiser, "Ends+ ways+ means= (bad) strategy," in Parameters 46, No. 4 (2016), p. 84.

24 Ibid.

25 Department of Prime Minister and Cabinet, Countering Terrorism and Violent Extremism: National Strategy.

26 Ibid.

27 Ibid.

28 Ibid.

29 Ibid.

30 John Battersby, "Facing Up! The Legal and Definitional Challenges of New Zealand's Approach to Terrorism," in New Zealand National Security: Challenges, Trends and Issues, eds. William Hoverd, Nick Nelson \& Carl Bradley (Auckland: Massey University Press, 2017).

31 Department of the Prime Minister and Cabinet, Looking Forward - Strengthening New Zealand Against Terrorism and Violent Extremism.

32 Ibid.

33 Ibid, p. 2.

34 Ibid.

35 Ibid, p.5.

36 John Battersby, "Security sector practitioner perceptions of the terror threat environment before the Christchurch attacks," Kotuitui: New Zealand Journal of Social Sciences Online, https://doi.org/10.1080/ 1177083X.2019.1701049.

37 Department of Prime Minister and Cabinet, Countering Terrorism and Violent Extremism: National Strategy, p. 5.

38 Andrew Hussey, The French Intafada: The Long War Between France and It's Arabs (Firrar, Straus and Giraud, London, 2014)

39 "Vikings vs Neo-Nazis: Battling the Far Right in Sweden," Al Jazerra, 21 March 2020. Available at https:/www.aljazeera.com/programmes/witness/2020/03/vikings-neo-nazis-battling-sweden-200319123918169.html.

40 John Battersby, Terrorism Where Terror Is Not: Australian and New Zealand Terrorism Compared, Studies in Conflict and Terrorism, 41:1 (2017).

41 "Auckland more diverse than London and New York," New Zealand Herald, 17 January 2016. Available at https://www.nzherald.co.nz/nz/news/article.cfm?c_id=1\&objectid=11575305.

42 "Just under half of Aucklanders have negative views of ethnic diversity, report suggests," Stuff. co.nz, 23 March 2020. Available at https://www.stuff.co.nz/national/politics/local-democracy-reporting/120506897/just-under-half-of-aucklanders-have-negative-views-of-ethnic-diversity-report-suggests. 43 Rachel Simon-Kumar, "The Multicultural Dilemma: Amid Rising Diversity and Unsettled Equity Issues, New Zealand Seeks to Address Its Past and Present," Migration Policy Institute, 5 September 
2019. Available at https://www.migrationpolicy.org/article/rising-diversity-and-unsettled-equity-issues-new-zealand

44 "Ihumātao protest: Video shows protester racially abusing police officer," Newshub, 7 August 2019. Available at https://www.newshub.co.nz/home/new-zealand/2019/08/ihumatao-protest-video-shows-protester-racially-abusing-police-officer.html. "Major ruction in Government over Shane Jones' 'racist' Indian remarks," Newshub, 3 March 2020. Available at https://www.newshub.co.nz/home/politics/2020/03/ major-ruction-in-government-over-shane-jones-racist-indian-remarks.html.

45 John Battersby, "The Ghost of New Zealand's Terrorism Past and Present," National Security Journal 1 (2019).

46 John Battersby \& Rhys Ball, "Christchurch in the context of New Zealand terrorism and right wing extremism," Journal of Policing, Intelligence and Counter Terrorism, 14:3 (2019). "SIS accused of breaching NZ Muslims' rights: It's 'unethical, misleading', says critic, Radio New Zealand. Available at https://www.rnz.co.nz/news/national/385487/sis-accused-ofbreaching-nz-muslims-rights-it-s-unethicalmisleading-says-critic. [Name Withheld] Personal Communication with the Author, 6 March 2020.

47 See Battersby \& Ball (2019), and Gilbert \& Elley (2020), both previously cited above.

48 Keiran Hardy, "Countering right wing extremism: lessons from Germany and Norway," Journal of Policing, Intelligence and Counter Terrorism, 14:3 (2019).

49 DPMC Paper, Looking Forward - Strengthening New Zealand Against Terrorism and Violent Extremism. ERS-19-SUB-0026, 26 September 2019, p. 11.

50 "Coronavirus: Queues outside Gun City as Kiwis panic-buy firearms amid COVID-19 lockdown," Newshub, 26 March 2020. Available at https:/www.newshub.co.nz/home/money/2020/03/coronavirus-no-justification-for-price-gouging-as-kiwis-enter-lockdown-consumer-nz.html?ref=ves-nextauto.

51 "Covid-19 lockdown: Don't panic-buy, we have enough, supermarkets urge," Radio New Zealand, 23 March 2020. Available at https://www.rnz.co.nz/national/programmes/checkpoint/audio/2018739790/ covid-19-lockdown-don-t-panic-buy-we-have-enough-supermarkets-urge

52 Wil Hoverd, Personal Communication to John Battersby, 8 May 2020.

53 "Protecting crowded places from terror attack," Line of Defence Magazine, Spring 2017. Available at https://defsec.net.nz/2017/10/01/protecting-crowded-places-terror-attack/; Nicholas Dynon, personal communication with John Battersby, 8 May 2020.

54 Anthony A. Braga, Philip J Cook, David M. Kennedy and Mark H. Moore, "The Illegal Supply of Firearms," Crime and Justice 29 (2002), pp.319-352; Wang-Sheng Lee and Sandy Suardi, "The Australian Firearms Buyback and its Effects on Gun Deaths," Contemporary Economic Policy 28: (2010) p.76; Wang-Sheng Lee and Sandy Suardi, "The Australian Firearms Buyback and its Effects on Gun Deaths," Contemporary Economic Policy 28: (2010) p.76; Duncan Chappell, Firearms regulation, violence and the mentally ill: A contemporary Antipodean appraisal," International Journal of Law and Psychiatry, 37 (2014), p.402; Stuart Gilmour, Kittima Wattanakamolkul and Maaya Sugai, "The Effect of the Australian National Firearms Agreement on Suicide and Homicide Mortality, 1978-2015, American Journal of Public Health 2018 108:11, pp.1511-1516; Michael Siegel, "Implications of the Australian Experience With Firearm Regulation For US Gun Policy, American Journal of Public Health, (2018) 108:11, pp.14381439; Bradley J. Bartos, Richard McCleary, Lorraine Mazerolle and Kelsy Luengen, "Controlling Gun Violence: Assessing the Impact of Australia's Gun Buyback Program Using a Synthetic Control Group Experiment," Prevention Science (2020) 21:1, p.35]

55 "Norway set to ban semi-automatic guns from 2021, 10 years after Utoya shooting," The Guardian, 27 February 2018. Available at https://www.theguardian.com/world/2018/feb/27/norway-guns-ban-semiautomatic-law.

56 "Trudeau announces Canada is banning assault-style weapons," 1 May 2020, The Guardian. Available at https://www.theguardian.com/world/2020/may/01/canada-assault-weapons-ban-trudeau-nova-scotia-shooting

57 Alan Stolberg, How Nation States Craft National Security Strategy Documents.

58 David Orrell, The Future of Everything: The Science of Prediction (Toronto: HarperCollins Publishers Ltd, 2007).

59 Dwight Eisenhower, Crusade in Europe (Baltimore: The Johns Hopkins University Press, 1997) p. 36.

60 John Gearson \& Hugo Rosemont, "CONTEST as Strategy: Reassessing Britain's Counterterrorism Approach," Studies in Conflict \& Terrorism, 38:12 (2015), p.1040. 